\title{
A Study on Miracles through the Holy Bible using Modified Induced Fuzzy Relational Maps (MIFRM)
}

\author{
A. Rajkumar* \\ Assistant Professor \\ Hindustan University, \\ Chennai - 603103
}

\author{
A. Victor Devadoss \\ Professor, \\ Loyola College, \\ Chennai - 600034
}

\author{
N. Jose Parvin Praveena \\ Assistant Professor \\ KCG college of Technology \\ Chennai - 600097
}

\begin{abstract}
This paper aims at studying at length the various reasons for miracles with incidents from the Holy Bible adopting the Modified Induced Fuzzy relational Maps, a generalization of Fuzzy Relational Maps. The content gives preliminaries of FRM and MIFRM with a descriptive account of the problem and the various miracles witnessed in the Bible using MIFRM. The data acquired is collated to conclude on the most essential component that results in the discharge of miracles in various instances.
\end{abstract}

Index Terms - Fuzzy Relational Maps, Modified Induced fuzzy relational Maps, Unsupervised, Bible.

\section{INTRODUCTION}

A Miracle is an event that apparently contradicts known scientific laws and is hence thought to be due to supernatural causes especially to an act of god. Miracles in the new testament had a purpose - miracles were performed to confirm the word (Mark 16:20), to create faith in Jesus Christ (John 20:30-31), to demonstrate that God is with Jesus (John $3: 2$ ), to prove that Jesus is the Christ, the Son of God, as prophesied (Matt 8:16-17). The New Testament narrates about thirty five miracles performed by Jesus. These miracles can be classified as Miracles of nature, Miracles of healing, and Miracles of resurrection. These miracles are listed below: [1]
Calming the storm

Feeding five thousand

Walking on water

Feeding four thousand

Coin in fish's mouth

Fig tree withered

Catch of fish

Water into wine

Another catch of fish

Cleansing of a Leper

Centurion's servant

Peter's mother-in-law

Paralyzed man

Woman with hemorrhage

Man with withered hand

Two blind men

Canaanite woman

Blind Bartimaeus

Blind man at Bethsaida

Deaf and mute man

Crippled woman

Man with dropsy
(Matthew 8:23-27)

(Matthew 14:13-21)

(Matthew 14:22-33)

(Matthew 15:32-38)

(Matthew 17:24-27)

(Matthew 21:22)

(Luke 5:1-11)

(John 2:1-11)

(John 21:1-11)

(Matthew 8:2-4)

(Matthew 8:5-13)

(Matthew 8:14-15)

(Matthew 9:2-8)

(Matthew 9:20-22)

(Matthew 12:10-13)

(Matthew 9:27-31)

(Matthew 15:21-28)

(Matthew 20:29-34)

(Mark 8:22-26)

(Mark 7:32-37)

(Luke 13:11-13)

(Luke 14:1-4)
Lepers

Malchus's ear

Capernaum Official's son

Sick at pool of Bethesda

Man blind from birth

Mutiple demon possessed man

Gerasene demoniac

Possessed man

Possessed Blind Mute man

Epileptic boy

Possessed man

Widow's son

Jairus' daughter

Rise of Lazarus

\author{
(Mark 7:11-19) \\ (Mark 22:50-51) \\ (John 4:46-54 ) \\ (John 5:1-15 ) \\ (John 9:1-4) \\ (Matthew 8:16-17) \\ (Matthew 8:28-34) \\ (Matthew 9:32-34) \\ (Matthew 12:22-23) \\ (Matthew 17:14-21) \\ (Mark 1:23-26 ) \\ (Luke 7:11-17) \\ (Matthew 9:18-19) \\ (John 11:1-44) [1].
}

The FRM model was introduced by W.B. Vasantha and Yasmin sultana in year 2000. This model is more applicable when the data in the first place is an unsupervised one. It is used to model several types of problems varying from gastric appetite behavior, popular political development etc. It is also used to model in robotics like plant control. This model works on the opinion of experts. This model has been used to study various social problems. In particular, the problem of health hazards faced by Rag pickers, the causes for school dropout which ultimately lead to child labour have been studied in the model. In order to bring out much stronger relationship among the attributes, a model called Modified Induced Fuzzy relational maps (MIFRM) was introduced by Thirusangu, K and P. Elumalai in the year 2012.

\section{FUZZY RELATIONAL MAPS (FRMS): 2.1 Preliminaries:[2]}

In our study, the elements of the domain space are taken from the real vector space of dimension $n$ and that of the range space are real vectors from the vector space of dimension $\mathrm{m}$ ( $m$ in general need not be equal to $n$ ). We denote by $R$ the set of nodes $R_{1}, \ldots, R_{m}$ of the range space, where $R_{i}=\left\{\left(x_{1}, x_{2}\right.\right.$, $\left.\ldots, \mathrm{x}_{\mathrm{m}}\right) / \mathrm{x}_{\mathrm{j}}=0$ or 1$\}$ for $\mathrm{i}=1, \ldots, \mathrm{m}$. If $\mathrm{x}_{\mathrm{i}}=1$ denotes the node $R_{i}$ is in the ON state and if $x_{i}=0$ denotes the node $R$ is in the OFF state. Similarly D denotes the nodes

$D_{1}, D_{2}, \ldots, D_{n}$ of the domain space where $D_{i}=\left\{\left(x_{1}, x_{2}, \ldots, x_{n}\right)\right.$ / $x_{j}=0$ or 1$\}$ for $i=1, \ldots$, n. If $x_{i}=1$, denotes the node $D_{i}$ is in the ON state and if $x_{i}=0$ denotes the node $D_{i}$ is in the OFF state.

Definition: 2.1.1: A FRM is a directed graph or a map from Domain Space to Range Space with concepts like policies or events etc. as nodes and causalities as edges. It represents casual relations between spaces $\mathrm{D}$ and $\mathrm{R}$. 
Definition 2.1.2: The directed edge from $D$ to $R$ denotes the casuality of D on R, called relations. Every edge in the FRM is weighted with a number in the set $\{0,1\}$.

Definition 2.1.3: Let $D_{i}$ and $R_{j}$ denote the two nodes of an FRM. Let $e_{i j}$ be the weight of the edge $D_{i} R_{j}, e_{i j} \in\{0.1\}$. The weight of the edge $D_{i} R_{j}$ is positive if increase in $D_{i}$ implies increase in $R_{j}$ or decrease in Di implies decrease in $R_{j}$. i.e., casuality of $D_{i}$ on $R_{j}$ is 1 . If $e_{i j}=0$ then $D_{i}$ does not have any effect on $R_{j}$. We do not discuss the cases when increase in $D_{i}$ implies decrease in $R_{j}$ or decrease in $D_{i}$ implies increase in $R_{j}$. When the nodes of the FRM are fuzzy sets, then they are called fuzzy nodes, FRMs with edge weights $\{0,1\}$ are called simple FRMs. Let $D_{1}, \ldots, D_{n}$ be the nodes of the domain space $D$ of an FRM and $R_{1}, \ldots, R_{m}$ be the nodes of the range space R of an FRM.

Definition 2.1.4: Let the matrix $E$ be defined as $E=\left(e_{i j}\right)$ where $\mathrm{e}_{\mathrm{ij}} \in\{0,1\}$; is the weight of the directed edge $\mathrm{D}_{\mathrm{i}} \mathrm{R}_{\mathrm{j}}$ (or $\mathrm{R}_{\mathrm{j}} \mathrm{D}_{\mathrm{i}}$ ), E is called the relational matrix of the FRM. It is pertinent to mention here that unlike the FCMs, the FRMs can be a rectangular matrix; with rows corresponding to the domain space and columns corresponding to the range space. This is one of the marked differences between FRMs and FCMs.

Definition 2.1.5: Let $D_{1}, \ldots, D_{n}$ and $R_{1}, \ldots, R_{m}$ be the nodes of an FRM. Let $D_{i} R_{j}\left(\right.$ or $R_{j} D_{i}$ ) be the edges of an FRM, $j=1,2$, $\ldots, m, i=1,2, \ldots, n$. The edges form a directed cycle if it possesses a directed cycle. An FRM is said to be a cycle if it does not possess any directed cycle.

Definition 2.1.6: An FRM with cycles is said to have a feed back when there is a feed back in the FRM, i.e. when the casual relations flow through a cycle in a revolutionary manner the FRM is called a dynamical system.

Definition 2.1.7: Let $D_{i} R_{j}\left(\right.$ or $\left.R_{j} D_{i}\right), 1 \leq j \leq m, 1 \leq \mathrm{i} \leq n$. When $R_{j}$ (or $D_{i}$ ) is switched on and if causality flows through edges of the cycle and if it again causes $R_{i}\left(D_{j}\right)$, we say that the dynamical system goes round and round. This is true for any node $R_{j}$ (or $D_{j}$ ) for $1 \leq \mathrm{i} \leq \mathrm{m}$, ( or $1 \leq \mathrm{j} \leq \mathrm{n}$ ). The equilibrium state of this dynamical system is called the hidden pattern. If the equilibrium state of the dynamical system is a unique state vector, then it is called a fixed point. Consider an FRM with $R_{1} \ldots R_{m}$ and $D_{1} \ldots D_{n}$ as nodes. For example let us start the dynamical system by switching on $R_{1}$ or $D_{1}$. Let us assume that the FRM settles down with $R_{1}$ and $R_{m}$ (or $D_{1}$ and $\left.\mathrm{D}_{\mathrm{n}}\right)$ on i.e. the state vector remains as $\left(\begin{array}{llll}1 & 0 & \ldots & 0\end{array}\right)$ in $\mathrm{R}$ [or $\left(\begin{array}{lll}1 & 0\end{array}\right.$ ... 01 1) in D], this state vector is called the fixed point. If the FRM settles down with a state vector repeating in the form $\mathrm{A}_{1} \rightarrow \mathrm{A}_{2} \rightarrow \ldots \rightarrow \mathrm{A}_{\mathrm{i}} \rightarrow \mathrm{A}_{1}$ or $\left(\mathrm{B}_{1} \rightarrow \mathrm{B}_{2} \ldots \mathrm{B}_{\mathrm{i}} \rightarrow \mathrm{B}_{1}\right)$ then this equilibrium is called a limit cycle.

\section{METHOD OF DETERMINATION OF HIDDEN PATTERN}

Let $R_{1}, \ldots, R_{m}$ and $D_{1}, \ldots, D_{n}$ be the nodes of a FRM with feedback. Let $E$ be the $n \times m$ relational matrix. Let us find a hidden pattern when $D_{1}$ is switched on i.e. when an input is given as vector $A_{1}=\left(\begin{array}{llllll}1 & 0 & 0 & 0 & \ldots\end{array}\right)$ in $D$ the data should pass through the relational matrix $\mathrm{M}$. This is done by multiplying $A_{1}$ with the relational matrix $M$. Let $A_{1} M=\left(k_{1}, \ldots, k_{m}\right)$ after thresholding and updating the resultant vector (say $\mathrm{B}$ )belongs to R. Now we pass on B into MT and obtain BMT. After thresholding and updating BMT we see the resultant vector say $A_{2}$ belongs to $D$. This procedure is repeated till we get a limit cycle or a fixed point.

\section{MODIFIED INDUCED FUZZY RELATIONAL MAPS (MIFRM)[3]}

Suppose that there are $n$ attributes, say $X_{1}, \ldots, X_{n}$ where $n$ is finite, associated with a domain and let $Y_{1}, \ldots, Y_{p}$ be the attributes associated with another domain. The connection matrix $\mathrm{M}$ of order $\mathrm{n} \times \mathrm{p}$ is obtained through the expert.

Let $\mathrm{C}_{1}$ be the initial input vector of order $1 \times \mathrm{n}$. A particular component, say $\mathrm{C}_{1}$, is kept on $\mathrm{ON}$ state and all other components on OFF state and pass the state vector $\mathrm{C}_{1}$ through the connection matrix $\mathrm{M}$.

To convert the resultant vector into a signal function, choose the first two highest values to $\mathrm{ON}$ state and other values to OFF state with 1 and 0 respectively.

Denote this process by the symbol.

The resulting vector is multiplied with $\mathrm{M}^{\mathrm{T}}$ and thresholding yields a new vector $D_{1}$.

This resulting vector is related with the connection matrix and that vector which gives the highest number of attributes to $\mathrm{ON}$ state is choose as $\mathrm{C}_{2}$. That is, for each positive entry we get a set of resultant vectors.

Among these vectors choose two vectors, out of which one with maximum number of 1 's and another with next maximum number of 1's. A new vector $\mathrm{C}_{2}$ is obtained by merging these two vectors.

If there are two or more vectors with equal number of 1's as $\mathrm{ON}$ state, choose the first occurring one as $\mathrm{C}_{2}$. Repeat the same procedure till a fixed point or a limit cycle is obtained.

This process is done to give due importance to each vector separately as one vector induced another or many more vector into ON state. Get the hidden pattern by the limit cycle or by getting a fixed point.

Next choose the vector with its second component in ON state and repeat the same process to get another cycle. This process was repeated for all the vectors separately. We observe the hidden pattern of some vectors found in all or many cases. Inference from this hidden pattern highlights the causes.

\section{DESCRIPTION AND ADOPTION OF MIFRM MODEL TO STUDY ABOUT MIRACLES USING HOLY BIBLE.}

A survey of around 50 Believers, priest and Pasteur living in Chennai was taken using a questionnaire. From the feedback, nodes were identifies as domain space and range space and reasons for miracles in the Holy bible were charted out to bring out the strong relationship among the attributes, using Modified Induced Fuzzy relational maps (MIFRM)

$S_{1}$ Human attitudes identified that release the power of Christ as miracles (domain space) include:[8] 
$\mathrm{D}_{1} \quad$ Faith

Faith is the substance of hope

Heb 11:1

Faith is the foundation of our hope:

Rom 8:24.25

Faith is the "title-deed" our pledge to things hope Heb 3:14

Faith is the conviction of things not seen Heb 11:3

Faith accepts even that which appears unreasonable Rom 4:1

Trusting commitment of one person to another, particularly of a person to God. Faith is the central concept of Christianity. One may be called a Christian only if one has faith.

$D_{2} \quad$ Hearing the word of God

So then, faith cometh by hearing, and hearing by the word of God, ie., hearkening to a higher authority.

Rom 10:17

$\mathrm{D}_{3} \quad$ Repentance

A feeling of regret, a changing of the mind, or a turning from sin to God.

(Genesis 6:6-7/ (1 Samuel 15:11,/1 Samuel 15:35)/

(Exodus 32:14).

$\mathrm{D}_{4} \quad$ Obedience

"To hear God's Word and act accordingly."

The person's obedient response to God's Word is a response of trust or faith. Thus, to really hear God's Word is to obey God's Word (Exodus 19:5; Jeremiah 7:23).

$\mathrm{D}_{5} \quad$ Trust

Confidence, a reliance or resting of the mind on the integrity, veracity, justice, friendship or other sound principle of another person, He that putteth his trust in the lord shall be safe (prov 29)

$\mathrm{D}_{6} \quad$ Endurance

"Stand one's ground; persevere; remain steadfast," and 'endure'. (Mt. 24:13) endurance" that does not lose hope in the face of obstacles, persecutions, trials, or temptations.

$\mathrm{D}_{7} \quad$ Humility

A personal quality in which an individual shows dependence on God and respect for other persons.

A recognition of one's sinfulness before a holy God obedience to God and submission to God (Psalms 51:17; Micah 6:8) (Isaiah 6:5(Deuteronomy 8:2(2 Kings 22:19; 2 Chronicles 34:37).

$\mathrm{D}_{8} \quad$ Complete surrender/ whole hearted acceptance It means being received with approval or pleasure. In the Bible, things or persons are often said to be acceptable to men or to God. Divine acceptance is more important.

(Genesis 4:7; Isaiah 59:2) Amos 6:6-8

Psalms 51:16-17; 1 Peter 5:5-6)

$\mathrm{D}_{9} \quad$ Persistence/ Perseverance in prayer Maintaining Christian faith through the trying times of life.
(Ephesians 6:18; Philippians 4:6) Ephesians 6:18 Hebrews 12:1

$\begin{array}{ll}\mathrm{S}_{2} & \begin{array}{l}\text { Emotional Quotient (EQ) of Christ while } \\ \text { performing miracles(Range space) [9] }\end{array}\end{array}$

$\mathrm{R}_{1} \quad$ Authority in the spiritual realm

In biblical usage, describes the absolute power and freedom of God, and claims that he is the source of all other authorization or power. "exousia" expresses both freedom and legal rights, in Greek

"There is no authority except from God" (Romans 13:1 RSV; see John 19:11). "Exousia" describes first the freedom of God to act (Luke 15:5; Acts 1:7). Second, it signifies the divinely given power and authority of Jesus Christ as deriving from the father (Matthew 28:18; John 10:18; John 17:2), enabling him to forgive sin (Mark 2:10), and signifying his power to heal and to expel demons, which he gave his disciples (Mark $3: 15)$.

$\mathrm{R}_{2} \quad$ Obedience to the Father

Christ's obedience stands in contrast to Adam's disobedience (Romans 5:12-21). A desire to obey the will of God motivated Jesus' actions (Luke 4:43; John 5:30). Jesus acted and spoke only as the father directed (John 3:34). By living a life of obedience, Jesus showed himself to be the Savior (Hebrews 5:7-10). Christ's work on the cross is viewed as a sacrifice of obedience (Romans 5:19; Hebrews 10:7-10).

$\mathrm{R}_{3} \quad$ Compassion

To feel passion with someone to enter sympathetically into their sorrow and pain.

(Philippians 1:8), Compassion finds its source in God's compassion (James 5:11). In compassion he has provided salvation and forgiveness (Luke 1:78).

\section{$\mathrm{R}_{4} \quad$ Patience}

An active endurance of opposition, not a passive resignation. Patience is endurance, steadfastness, long suffering, and forbearance.

God is patient (Romans 15:5). He is slow to anger in relation to the Hebrews (Exodus 34:6; Numbers 14:18, Nehemiah 9:17; Psalms 86:15; Isaiah 48:9; Hosea 11:8-9).

$\mathrm{R}_{5} \quad$ Mercy/ Merciful

A personal characteristic of care for the needs of others.

God's mercy is bound up with his covenant with Israel. He is merciful to them. Because he chose them (Exodus 33:19; 2 Kings 13:23; Isaiah 54:10, Isaiah 63:7). God's mercy is never just a feeling but is expressed by his action: Providing for Israel in the wilderness (Nehemiah 9:19; Isaiah 49:10) and delivering her from enemies (Psalms 69:16-21;Psalms 79: 811; Isaiah 30:18; Jeremiah 42:11-12).

God's mercy is the very source of his people's life (Psalms 103:4; Psalms 119:1)

\section{$\mathrm{R}_{6} \quad$ Loving}

Unselfish, loyal, and benevolent concern for the well-being of another. In 1 Corinthians 13:1, Paul described "love" as a "more excellent way" than tongues or even preaching. The New Testament maintains this estimation of love throughout. It is a relationship of self-giving which results from God's activity in Christ. The source of Christian love is God 
(Romans 5:8), and the believer's response of faith makes love a human possibility (Romans 5:5).

$\mathrm{R}_{7} \quad$ Forgiving/ Forgiveness

An act of God's grace to forget forever and not hold people of faith accountable for sins they confess; to a lesser degree the gracious human act of not holding wrong acts against a person. Forgiveness has both divine and human dimensions. In the divine relationship, it is first of all, the gracious act of God by which believers are put into a right relationship to God and transferred from spiritual death to spiritual life through the sacrifice of Jesus.

Jesus is the perfect and final Sacrifice through which God's forgiveness is mediated to every person (Romans 3:25; Hebrews 10:11-12).

\section{$\mathrm{R}_{8} \quad$ Restraint/ Anger}

To hold back to check, to hold from action proceeding or advancing, either by physical or moral force, or by an interposing obstacle.

\section{$\mathrm{R}_{9} \quad$ Forbearance}

Forbearance refers to God's patience expressed in God's willingness to hold back judgment for a time.

Now using the expert's opinion. From the figure given below the following relation matrices obtained .By taking Human attitudes that release the power of Christ as miracles $\mathrm{D}_{1}, \mathrm{D}_{2}$, $\mathrm{D}_{3}, \ldots, \mathrm{D}_{9}$ as the rows and Emotional Quotient (EQ) of Christ while performing miracles $R_{1}, R_{2}, R_{3}, \ldots, R_{9}$ as the columns.

\section{EXPERT OPINION}

(Fig)

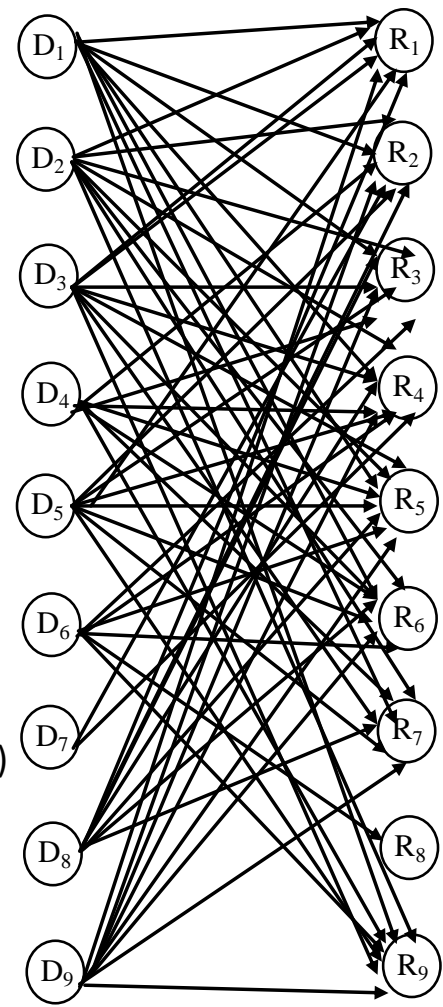

$$
\begin{aligned}
& \begin{array}{llllllllll}
\mathrm{R}_{1} & \mathrm{R}_{2} & \mathrm{R}_{3} & \mathrm{R}_{4} & \mathrm{R}_{5} & \mathrm{R}_{6} & \mathrm{R}_{7} & \mathrm{R}_{8} & \mathrm{R}_{9}
\end{array} \\
& \mathrm{C}_{1}\left(\begin{array}{lllllllll}
1 & 1 & 1 & 1 & 1 & 1 & 1 & -1 & 1
\end{array}\right) \\
& \begin{array}{l|lllllllll}
\mathrm{C}_{2} & 1 & 1 & 1 & 1 & 1 & 1 & 1 & 0 & 1
\end{array} \\
& \begin{array}{l|lllllllll}
\mathrm{C}_{3} & 1 & 1 & 1 & 1 & 1 & 1 & 1 & -1 & 1
\end{array} \\
& \mathrm{E}_{1}=\begin{array}{c|ccccccccc}
\mathrm{C}_{4} & 0 & 1 & 1 & 1 & 1 & 1 & 1 & 0 & 1 \\
\mathrm{C}_{5} & 1 & 1 & 1 & 1 & 1 & 1 & 1 & -1 & 1
\end{array} \\
& \begin{array}{l|lllllllll}
\mathrm{C}_{6} & 0 & 0 & 1 & 1 & 1 & 1 & -1 & 1 & 1
\end{array} \\
& \begin{array}{l|lllllllll}
\mathrm{C}_{7} & 0 & 1 & 0 & 1 & 0 & 0 & 0 & 0 & 0
\end{array} \\
& \begin{array}{l|lllllllll}
\mathrm{C}_{8} & 1 & 1 & 1 & 1 & 1 & 1 & 1 & 0 & 1
\end{array} \\
& \mathrm{C}_{9}\left(\begin{array}{lllllllll}
1 & 1 & 1 & 1 & 1 & 1 & 1 & -1 & 1
\end{array}\right)
\end{aligned}
$$

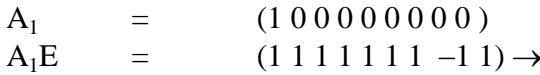

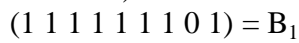

$$
\begin{aligned}
& \mathrm{B}_{1} \mathrm{E}_{1}{ }^{\mathrm{T}}=\left(\begin{array}{lllllllll}
8 & 8 & 8 & 7 & 8 & 6 & 2 & 8 & 8
\end{array}\right) \rightarrow \\
& (111111111111)=A_{2} \\
& \mathrm{~A}_{2} \mathrm{E}_{1}=\left(\begin{array}{lllllllll}
6 & 8 & 8 & 9 & 8 & 8 & 8 & -5 & 8
\end{array}\right) \\
& \rightarrow\left(\begin{array}{lllllllll}
1 & 1 & 1 & 1 & 1 & 1 & 1 & 0 & 1
\end{array}\right)=\mathrm{B}_{2}
\end{aligned}
$$

\begin{tabular}{|c|c|c|}
\hline Step no & INPUT VECTOR & LIMIT POINT \\
\hline 1 & 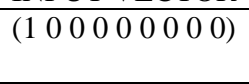 & $\left.\begin{array}{lllllllllll} & (1 & 1 & 1 & 1 & 1 & 1 & 1 & 1 & 1\end{array}\right)$ \\
\hline 2 & 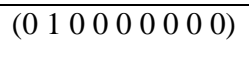 & $\left.\begin{array}{llllllllll} & (1 & 1 & 1 & 1 & 1 & 1 & 1 & 1 & 1\end{array}\right)$ \\
\hline 3 & $\left(\begin{array}{lllllllll}0 & 0 & 1 & 0 & 0 & 0 & 0 & 0 & 0\end{array}\right)$ & $\left.\begin{array}{lllllllll}(1 & 1 & 1 & 1 & 1 & 1 & 1 & 1 & 1\end{array}\right)$ \\
\hline 4 & $\left(\begin{array}{lllllllll}0 & 0 & 0 & 1 & 0 & 0 & 0 & 0 & 0\end{array}\right)$ & $\left.\begin{array}{llllllllll}(1 & 1 & 1 & 1 & 1 & 1 & 1 & 1 & 1\end{array}\right)$ \\
\hline 5 & 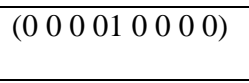 & $\left.\begin{array}{llllllllll}(1 & 1 & 1 & 1 & 1 & 1 & 1 & 1 & 1\end{array}\right)$ \\
\hline 6 & $\left(\begin{array}{llllllllllll}0 & 0 & 0 & 0 & 0 & 100 & 0\end{array}\right)$ & $\left.\begin{array}{lllllllllll} & (1 & 1 & 1 & 1 & 1 & 1 & 1 & 1 & 1\end{array}\right)$ \\
\hline 7 & $\left(\begin{array}{lllllllll}0 & 0 & 0 & 0 & 0 & 0 & 1 & 0 & 0\end{array}\right)$ & 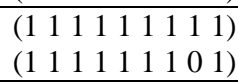 \\
\hline 8 & $\left(\begin{array}{lllllllll}0 & 0 & 0 & 0 & 0 & 0 & 0 & 1 & 0\end{array}\right)$ & $\left.\begin{array}{llllllllll} & (1 & 1 & 1 & 1 & 1 & 1 & 1 & 1 & 1\end{array}\right)$ \\
\hline 9 & $\left(\begin{array}{lllllllll}0 & 0 & 0 & 0 & 0 & 0 & 0 & 0 & 1\end{array}\right)$ & $\left(\begin{array}{lllllllll} & 1 & 1 & 1 & 1 & 1 & 1 & 1 & 1\end{array}\right)$ \\
\hline
\end{tabular}

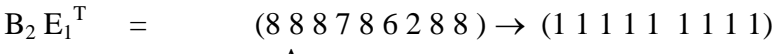

$$
\begin{aligned}
& =\mathrm{A}_{3}
\end{aligned}
$$

(where $\rightarrow$ denotes the resultant vector after thresholding and updating)

$\mathrm{A}_{2}=\mathrm{A}_{3}$.

Hence the pair of limit point is

(11 111111111$)(111111101)$

The limit points for different inputs are given in the following table. 


\section{USING MODIFIED INDUCED FUZZY RELATIONAL MAPS (MICFRM)}

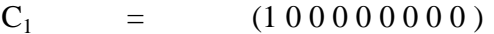

$$
\begin{aligned}
& \mathrm{C}_{1} \mathrm{E}_{1}=\left(\begin{array}{l}
1 \\
\mathrm{C}_{1}
\end{array}\right.
\end{aligned}
$$

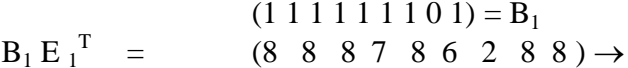

$$
\begin{aligned}
& \left(\begin{array}{lllllllll}
1 & 1 & 1 & 1 & 1 & 1 & 1 & 1 & 1
\end{array}\right)=\mathrm{C}_{1}{ }^{\prime}
\end{aligned}
$$

\begin{tabular}{|c|c|c|}
\hline & ec & \\
\hline $\mathrm{C}_{1}^{1}$ & $=$ & 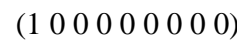 \\
\hline $\mathrm{C}_{1}^{2}$ & $=$ & 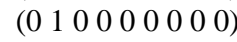 \\
\hline $\mathrm{C}_{1}^{3}$ & $=$ & 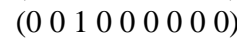 \\
\hline $\mathrm{C}_{1}^{4}$ & $=$ & 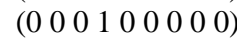 \\
\hline $\mathrm{C}_{1}{ }^{5}$ & $=$ & $\left(\begin{array}{llllllll}0 & 0 & 0 & 0 & 1 & 0 & 0 & 0\end{array}\right)$ \\
\hline $\mathrm{C}_{1}{ }^{6}$ & $=$ & 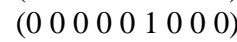 \\
\hline $\mathrm{C}_{1}{ }^{7}$ & $=$ & 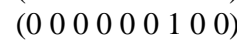 \\
\hline $\mathrm{C}_{1}{ }^{8}$ & $=$ & 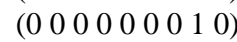 \\
\hline $\mathrm{C}_{1}^{9}$ & $=$ & $\left(\begin{array}{lllllllll}0 & 0 & 0 & 0 & 0 & 0 & 0 & 0 & 1\end{array}\right)$ \\
\hline
\end{tabular}

\section{Case 1}

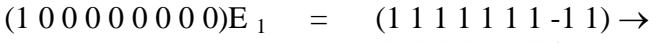

$$
\begin{aligned}
& \text { (1 } 1111111101) \\
& (111111101) \mathrm{E}_{1}^{\mathrm{T}}=(888786288) \rightarrow \\
& \text { (1 } 111111111 \text { ), row sum is } 9 \text {. }
\end{aligned}
$$

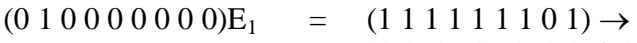

$$
\begin{aligned}
& \left(\begin{array}{lllllllll}
1 & 1 & 1 & 1 & 1 & 1 & 1 & 0 & 1
\end{array}\right) \\
& \left(\begin{array}{lllllll}
1 & 1 & 1 & 1 & 1 & 1 & 101
\end{array}\right) \mathrm{E}_{1}{ }^{\mathrm{T}}=(888786288) \rightarrow \\
& \text { (1 } 11111111111 \text { ), row sum is } 9 \text {. }
\end{aligned}
$$

Case 3

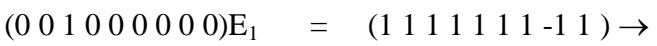

$$
\begin{aligned}
& \left(\begin{array}{lllllllll}
1 & 1 & 1 & 1 & 1 & 1 & 1 & 0 & 1
\end{array}\right) \\
& (111111101) \mathrm{E}_{1}{ }^{\mathrm{T}}=(888786288) \rightarrow
\end{aligned}
$$$$
\text { (1 } 1111111111 \text { ), row sum is } 9 \text {. }
$$

\section{Case 4}

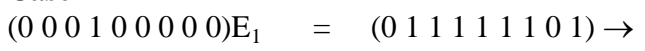
$\left(\begin{array}{lllllllll}0 & 1 & 1 & 1 & 1 & 1 & 1 & 0 & 1\end{array}\right)$

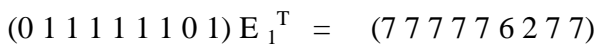
(1 111111111 ), row sum is 9 .

\section{Case 5}

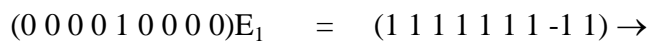$$
\left(\begin{array}{lllllllll}
1 & 1 & 1 & 1 & 1 & 1 & 1 & 0 & 1
\end{array}\right)
$$

$(111111101) \mathrm{E}_{1}{ }^{\mathrm{T}}=(888786288) \rightarrow$ (1 111111111111 ), row sum is 9 .

Case 6

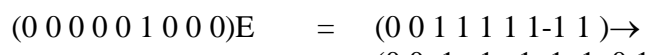
$\left(\begin{array}{lllllllll}0 & 0 & 1 & 1 & 1 & 1 & 1 & 0 & 1\end{array}\right)$

$(001111101) \mathrm{E}_{1}{ }^{\mathrm{T}}=(666666166) \rightarrow$ (1 1111111111$)$, row sum is 9 .

\section{Case 7}

$(000000100) \mathrm{E}_{1}=\left(\begin{array}{lllllll}0 & 01000000\end{array}\right) \rightarrow$

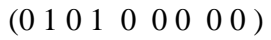

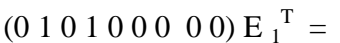

\section{Case 8}

$(000000010) \mathrm{E}_{1}=(111111101) \rightarrow$

(1 $\left.\begin{array}{lllllllll}1 & 1 & 1 & 1 & 1 & 1 & 0 & 1\end{array}\right)$

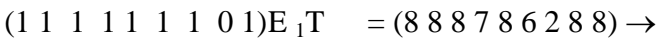

(1 1111111111 ), row sum is 9 .

Case 9

\begin{tabular}{|c|c|c|c|}
\hline $\begin{array}{c}\text { Step } \\
\text { no }\end{array}$ & INPUT VECTOR & LIMIT POINT & $\begin{array}{c}\text { Triggering } \\
\text { patterns }\end{array}$ \\
\hline 1 & 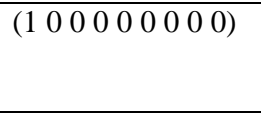 & 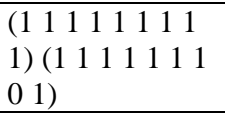 & $\mathrm{C}_{1} \Rightarrow \mathrm{C}_{1}$ \\
\hline 2 & $\left(\begin{array}{lllllllll}0 & 1 & 0 & 0 & 0 & 0 & 0 & 0 & 0\end{array}\right)$ & 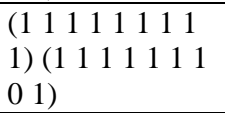 & $\mathrm{C}_{2} \Rightarrow \mathrm{C}_{1}$ \\
\hline 3 & $\left(\begin{array}{lllllllll}0 & 0 & 1 & 0 & 0 & 0 & 0 & 0 & 0\end{array}\right)$ & 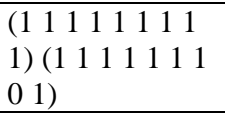 & $\mathrm{C}_{3} \Rightarrow \mathrm{C}_{1}$ \\
\hline 4 & 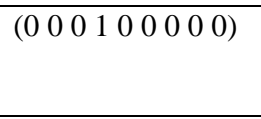 & $\begin{array}{l}\left(\begin{array}{lllllllll} & 1 & 1 & 1 & 1 & 1 & 1 & 1 \\
1) & \left(\begin{array}{llllllllll}1 & 1 & 1 & 1 & 1 & 1 & 1 & 1\end{array}\right. \\
0 & 1\end{array}\right) \\
\end{array}$ & $\mathrm{C}_{4} \Rightarrow \mathrm{C}_{1}$ \\
\hline 5 & 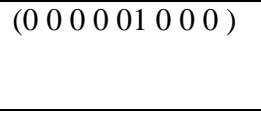 & 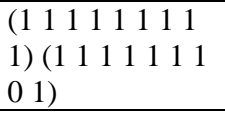 & $\mathrm{C}_{5} \Rightarrow \mathrm{C}_{1}$ \\
\hline 6 & 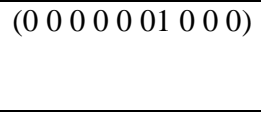 & $\begin{array}{l}\left(\begin{array}{lllllllll}1 & 1 & 1 & 1 & 1 & 1 & 1 & 1 \\
1) & (1 & 1 & 1 & 1 & 1 & 1 & 1 \\
0 & & \end{array}\right) \\
\end{array}$ & $\mathrm{C}_{6} \Rightarrow \mathrm{C}_{1}$ \\
\hline 7 & $\left(\begin{array}{lllllllll}0 & 0 & 0 & 0 & 0 & 0 & 1 & 0 & 0\end{array}\right)$ & 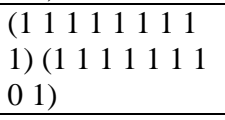 & $\mathrm{C}_{7} \Rightarrow \mathrm{C}_{1}$ \\
\hline 8 & $\left(\begin{array}{lllllllll}0 & 0 & 0 & 0 & 0 & 0 & 0 & 1 & 0\end{array}\right)$ & 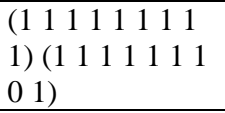 & $\mathrm{C}_{8} \Rightarrow \mathrm{C}_{1}$ \\
\hline 9 & $\left(\begin{array}{lllllllll}0 & 0 & 0 & 0 & 0 & 0 & 0 & 0 & 1\end{array}\right)$ & 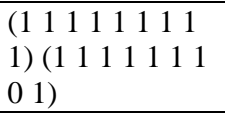 & $\mathrm{C}_{9} \Rightarrow \mathrm{C}_{1}$ \\
\hline
\end{tabular}

$(000000001) \mathrm{E}_{1}=\left(\begin{array}{llllll}1 & 111111-1\end{array}\right) \rightarrow$

$\left(\begin{array}{lllllllll}1 & 1 & 1 & 1 & 1 & 1 & 1 & 0 & 1\end{array}\right)$

$(111111101) \mathrm{E}_{1}{ }^{\mathrm{T}}=(888786288) \rightarrow$

(1 11111111111 ), row sum is 9 .

Therefore new input vector

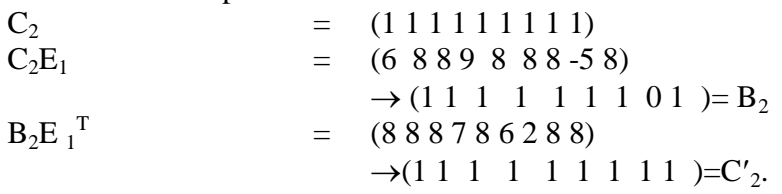

$\mathrm{C}_{1}^{\prime}=\mathrm{C}_{2}^{\prime}$

The binary pair of limit point is

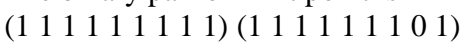


The merged graph triggering pattern

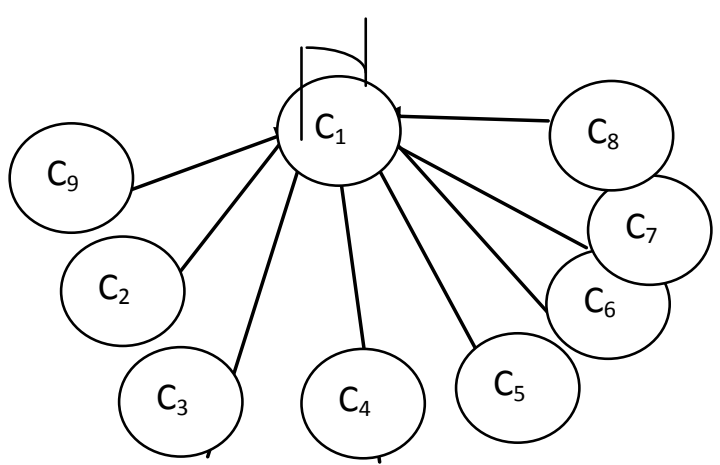

\section{CONCLUSION}

While analyzing MIFRM, when the concept $\mathrm{D}_{1}$ "faith is in the on state, the other concepts $\mathrm{D}_{2}, \mathrm{D}_{3}, \mathrm{D}_{4}, \mathrm{D}_{5}, \mathrm{D}_{6}, \mathrm{D}_{7}, \mathrm{D}_{8}$, $\mathrm{D}_{9}$, are also in the on state.

Thus it is concluded that Faith strengthens prayer, which in turn gives one the patience to wait on God and re-inforce the fact that belief in God and His promises would fetch imperishable rewards in the Heavenly realm.

"But without faith it is impossible to please him" (Hebrews $11: 6)$

Strong faith is a compass that indicates how God will supply those needs

"Receiving basic physical needs

(Matt 6:31-32)

Having wisdom to know what to say in tough witnessing situations

(Matt 10:18-20)

Knowing how to pray

Dealing with suffering

Coping with illness

Resisting temptation

Overcoming worry

Coping with trials

Facing intense pressures

(Rom 8:26)

(Rom 8:18-30)

( 2 cor.12:7-10)

(Rom .6:1-23)

(1 pet.5:7)

(Jas.1:5)

(2 Cor.1:8-11)

Needing comfort

(2 Cor .1:3-7)

Some of results given by experts on how faith leads to miracles are given below:

1. The centurion's servant,

2. The afflicted woman
3. The demoniac boy

(Matt 8:5-13,Luke 7:1-10)

Matt 9:20-22,mark 5:25-34)

4. The Ten lepers

(Matt 17:14-21,mark 9:14-29)

5. The Daughter of Jairus raised

6. The Two blind men near Jericho.

\section{SUGGESTIONS:}

The five phases of Faith go hand in hand with five fundamental truths of god

God has a plan for me

God is with me

God will make a way

God isn't surprised by death

God brings dreams to life

Faith is a gift of god (Rom 12:3)

We are sanctified by faith (Acts 26:18)

Jesus Christ dwells in our heart by faith (Galatians 3:22)
God's grace is received by faith

(Ephesians 2:8)

\section{FAITH IN EXERCISE}

Justified by faith (Rom :5:1)-our release

Saved through Faith (Eph .2:8) -our Deliverance

Sanctified by Faith (Acts 26:18)-our position

Purified by Faith (Acts 15:9)- Our Condition.

FAITH'S PROGRESS (as recorded in Psalm 37)

Trust in the lord - salvation

Delight in the lord -Communion

Commit thy Way to the lord-Guidance

Rest in the Lord -Patience

Wait on the lord - Hope

PRECIOUS FAITH (as recorded 2peter 1:1) The word of Faith (Rom.10:8)-Christ's work The object of faith (Eph.1:13) Christ's person The basis of Faith (Rom .10:17)-God's word The result of Faith (Eph.2:8)-Man's Salvation Faith is a gift of god (Rom 12:3) we are sanctified by Faith (Acts 26:18)

Jesus Christ dwells in our heart by faith (Galatians 3:22) God's grace is received by faith (Ephesians 2:8)

\section{FUTURE WORK}

Miracles will be analyzed by using fuzzy model.

\section{ACKNOWLEDGEMENT}

The authors wish to thank A. Praveen Prakash and C Jayalatha.

\section{REFERENCES}

[1] The Holy Bible -The bible society of India- ISBN81221- 0246-8.

[2] Vasantha Kandasamy W.B and Smarandache Florentin 'Fuzzy Cognitive Maps and Neutrosophic Cognitive Maps', Xiquan, Phoenix (2003)

[3] Thirusangu, K, Elumalai, Analysis of Health hazards faced by rag pickers of Chennai city Using Modified induced Fuzzy relational maps, (2012)

[4] Axelrod,R. (1976). Structure of decision : The cognitive maps of political elites. Princeton University.

[5] Kosko,B., "Fuzzy Cognitive Maps", International Journal of man-machine studies, Jan(1986)

[6] Kosko, B. 1997 Neural Networks and Fuzzy System Prentice Hall of India.

[7] Kosko ,B. Hidden patterns in Combined and adaptive Knowledge Networks, International Conference of Neural Networks(ICNN-86)1988 377-393.

[8] A. Victordevadoss, A. Rajkumar, N.Jose Parvin Praveena, A Study on Miracles through Holy Bible using Combined Overlap Block Fuzzy Cognitive Maps (COBFCMS) International Journal of Computer Applications (0975 - 8887) Volume 53- No.15, September 2012.

[9] A. Victordevadoss, A. Rajkumar, N.Jose Parvin Praveena, A Study on miracles through Holy bible using Induced Fuzzy Cognitive Maps (IFCMS) International 
Journal of Computer Applications (0975 - 8887) Volume 54- No.15, October 2012.

[10] Vasantha,W.B., P.Elumalai and Mary John. M., Analysis of Health hazards faced by rag pickers of Chennai city Using Fuzzy relational maps, Proceedings of National Conference on mathematical modeling and Analysis, BITS Pilani, (2004)

[11] Vasantha,W.B., and Yasmin, S., FRM to Analyse the Employee - Employer Relationship Model, Journal of Bihar Mathematical Society, 25-34 (2001).

[12] Thirusangu, K, Elumalai, Analysis of Health hazards faced by rag pickers of Chennai city Using Modified induced Fuzzy relational maps, (2012)

[13] Mendel, J., Uncertain Rule-Based Fuzzy Logic Systems; Introduction and New Directions. NJ, Prentice-Hall, (2001)

[14] Miao Y., and Liu C., On Causal Inference in Fuzzy Cognitive Map, IEEE Transaction on Fuzzy Systems, 8, no.1, 107-120 (2000)
[15] Mizumoto, M., and Zimmermann, H.J., "Comparisons of Fuzzy Reasoning Methods”, Fuzzy Sets and Systems, 8, 253-283 (1982).

[16] Ozen, T., Garibaldi, J.M., and Musikasuwan, S., Preliminary Investigations into Modelling the Variation in Human Decision Making, Information Processing and Management of Uncertainty in Knowledge Based Systems, Perugia, Italy, (July 2004).

[17]Pathinathan, T., Thirusangu, K., and Mary John, M., On School dropouts of School Children - A Fuzzy Approach, Acta Ciencia Indica Vol. XXXIM, No.4,1279 1299(2005).

[18] Pathinathan, T., Thirusangu, K., and Mary John, M.,A Mathematical Approach to Issues which Increase Dropouts in School Education. Ind. Journal of Millennium Development studies- An International Journal, Vol 1, No.2, 243-250(2006). 